Vol.3 No.1 Hal. $39-44$

Juni 2020

\title{
Pengembangan LKPD Berbasis Science, Technology, Engineering, and Mathematics Untuk Menumbuhkan Keterampilan Literasi Sains Siswa Kelas X MIA SMA NEGERI 14 Medan T.P 2019/2020
}

\author{
${ }^{(1)}$ Ade Silvia, ${ }^{(2)}$ Halim Simatupang \\ Prodi Pendidikan Biologi Jurusan Biologi FMIPA, Universitas Negeri Medan ${ }^{(1)}$ \\ Corresponding author : halim@unimed.ac.id (2)

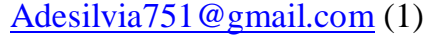

\begin{abstract}
ABSTRAK
Penelitian ini bertujuan untuk merancang dan menghasilkan Lembar Kegiatan Peserta Didik (LKPD) berbasis Sains Technology Engineering and Mathematics (STEM) pada materi Virus. Desain penelitian yang digunakan adalah jenis penelitian dan pengembangan. Subjek dalam penelitian ini adalah Ahli Materi, Ahli Pembelajaran, Ahli Desain, Guru bidang studi Biologi dan siswa kelas X-MIA-3 SMA Negeri 14 Medan. Pengumpulan data dilakukan dengan instrumen berupa lembar penilaian validasi ahli materi, ahli pembelajaran, ahli desain, penilaian guru dan tanggapan/respon siswa. Analisis data menggunakan analisis deskriptif kuantitatif dan kualitatif. Perancangan LKPD berbasis STEM dilakukan dengan menggunakan model pengembangan instruksional ADDIE yaitu melalui tahap Analysis, Development, Implementation, dan Evaluation karena pada model ini setiap tahap dilakukan revisi hingga didapatkan produk LKPD yang lebih baik. Hasil penelitian menunjukkan bahwa perancangan LKPD berbasis STEM berdasarkan penilaian ahli materi diperoleh persentase rata-rata $87,5 \%$ dengan kriteria sangat layak, penilaian ahli pembelajaran diperoleh persentase ratarata 92,5\% dengan kriteria sangat layak, penilaian ahli desain diperoleh persentase rata-rata 78,7\% dengan kriteria layak.. Hasil dari penggunaan LKPD Berbasis Pendekatan STEM yang dirancang dalam menumbuhkan keterampilan literasi sains diperoleh skor rata-rata 81,7 dengan jumlah persentase ketuntasan sebesar 85,2\% dengan jumlah peserta didik yang tuntas sebanyak 29 orang. LKPD Berbasis STEM pada materi Virus yang telah dirancang memperoleh kriteria penilaian"Sangat Tinggi" dan telah memenuhi persyaratan efektif digunakan dalam menumbuhkan keterampilan literasi sains serta layak digunakan dalam proses pembelajaran Biologi pada materi virus.
\end{abstract}

Kata Kunci : Pengembangan LKPD, STEM, Model ADDIE

\begin{abstract}
This study aims was to design and produce a student worksheet based on Science Technology Engineering and Mathematics (STEM) on Virus material. The research design used was a type of research and development. The subjects in this study were Material Expert, Learning Expert, Design Expert, Teacher in Biology and Class X-MIA-3 SMA N 14 Medan. Data collection was carried out with instruments in the form of material expert, learning expert, design expert, teacher in biology, and student response sheets. Data analysis uses quantitative and qualitative descriptive analysis. The student worksheet development based on STEM design was using ADDIE instructional development models through the Analysis, Development, Implementation, and Evaluation stages because in this model each stage was revised to obtain a better LKPD product. The results showed that the design student worksheet development based on STEM on expert content assessment obtained an average percentage of $87,5 \%$ with very decent criteria, assessment of learning experts obtained an average percentage of $92,5 \%$ with very feasible criteria, design expert judgment obtained an average percentage an average of 78,75\% with worthy criteria. The results of using STP-based LKPD approach designed in growing scientific literacy skills obtained an average score of 81.7 with a total percentage of completeness of $85.2 \%$ with the number of students who completed as many as 29 people. The student worksheet development based on STEM on Virus material that has been designed obtains "Very High" assessment criteria and has met the effective requirements used in growing scientific literacy skills and suitable for use in the Biology learning process on virus material.
\end{abstract}

Keywords : Student Worksheet Development, STEM, ADDIE model. 


\section{PENDAHULUAN}

\section{Latar Belakang}

STEM merupakan pendekatan pembelajaran yang menghubungkan empat bidang yaitu sains, teknologi, teknik dan matematika menjadi satu kesatuan yang holistik. Tujuan STEM dalam dunia pendidikan sejalan dengan tuntutan pendidikan abad 21 , yaitu agar peserta didik memiliki keterampilan literasi sains dan teknologi nampak dari membaca, menulis, mengamati, melakukan keterampilan sains, serta mampu mengembangkan kompetensi yang telah dimilikinya untuk diterapkan dalam menghadapi permasalahan dalam kehidupan sehari-hari yang terkait bidang ilmu STEM. Seiring perkembangan zaman dimana tuntutan abad 21 bahwa pendidikan harus dikaitkan dengan sains, teknologi, teknik dan matematika, maka sangat diperlukan LKPD Berbasis STEM agar pendidikan tidak tertinggal. Namun tidak semua sekolah dapat menerapkan LKPD berbasis STEM ini, dikarenakan beberapa faktor salah satunya adalah keterbatasan fasilitas yang ada di sekolah. Penguasaan Ilmu Pengetahuan dan Teknologi (IPTEK) saat ini menjadi kunci penting dalam menghadapi tantangan di masa depan. Berbagai tantangan yang muncul antara lain berkaitan dengan peningkatan kualitas hidup, pemerataan pembangunan, dan kemampuan untuk mengembangkan sumber daya manusia. Untuk itu, pendidikan sains sebagai bagian dari pendidikan berperan penting untuk menyiapkan peserta didik yang memiliki literasi sains, yaitu yang mampu berpikir kreatif, logis, dan berinisiatif dalam menanggapi isu di masyarakat yang diakibatkan oleh dampak perkembangan ilmu pengetahuan alam dan teknologi. Pendidikan sains diharapkan dapat menjadi wahana bagi peserta didik untuk mempelajari diri sendiri dan alam sekitar, serta prospek pengembangan lebih lanjut dalam menerapkannya di dalam kehidupan sehari-hari. Dengan demikian, ketika peserta didik mengusai literasi sains maka akan mampu memahami lingkungan hidup dan masalahmasalah lain yang dihadapi oleh masyarakat modern yang sangat bergantung dengan perkembangan ilmu pengetahuan dan teknologi.

\section{Perumusan Masalah}

Berdasarkan hasil observasi dan hasil wawancara yang dilakukan oleh peneliti di SMA Negeri 14 Medan bahwa permasalahan yang terdapat pada saat proses pembelajaran biologi adalah 1) Pembelajaran masih terpusat kepada guru, 2) Siswa malu bertanya, 3) Keterampilan literasi sains siswa masih rendah, 4) Guru belum sepenuhnya menggunakan LKPD, 5) LKPD yang disusun dan digunakan masih sangat sederhana yang hanya berisi soal-soal kognitif. Hal ini terlihat bahwa keterampilan literasi sains dilihat dari penyelesaian masalah dalam mengikuti pembelajaran biologi dilihat dari aktivitas pembelajaran siswa di kelas. Dengan demikian pembelajaran yang seharusnya terpusat pada peserta didik belum sepenuhnya terwujud. Sehingga untuk mencapai keberhasilan pembelajaran, selain penggunaan pendekatan pembelajaran yang tepat, penggunaan bahan ajar pun harus sesuai agar keterampilan literasi sains siswa dapat meningkat. Bahan ajar memainkan peran penting dalam memastikan efektivitas kegiatan belajar mengajar, salah satunya adalah lembar kerja peserta didik (LKPD) (Pertiwi, R. S., 2017). Oleh karena itu, pengembangan LKPD yang disesuaikan dengan kondisi dan kebutuhan peserta didik dianggap perlu dilakukan

\section{Tujuan Penelitian}

Sehingga berdasarkan pengamatan dan hasil pengumpulan data yang dilakukan maka penelitian ini bertujuan untuk; 1) mengetahui penilaian ahli materi terhadap kelayakan LKPD berbasis STEM yang dirancang pada materi virus, 2) mengetahui penilaian ahli pembelajaran terhadap kelayakan LKPD berbasis STEM yang dirancang pada materi virus, 3) mengetahui penilaian ahli desain terhadap kelayakan LKPD berbasis STEM yang dirancang pada materi virus, 4) mengetahui penilaian guru terhadap kelayakan LKPD 
Silvia A, Simatupang H : Pengembangan LKPD Berbasis Science, Technology, Engineering, and Mathematics Untuk Menumbuhkan Keterampilan Literasi Sains Siswa Kelas X MIA SMA Negeri 14 Medan TP 2019/2020

berbasis STEM yang dirancang pada materi virus, 5) mengetahui tanggapan siswa terhadap LKPD berbasis STEM pada materi virus yang dirancang dan 6) mengetahui efektifitas LKPD dalam menumbuhkan keterampilan literasi sains siswa pada pengembangan LKPD dengan pendekatan STEM pada siswa kelas X MIA SMA semester I.

\section{METODE PENELITIAN}

Penelitian ini menggunakan metode Kuantitatif dan kualitatif dimana data kuantitatif sendiri didapatkan dari hasil validasi ahli materi, ahli pembelajaran, ahli desain, penilaian guru dan data kualitatif sendiri dijabarkan dalam bentuk deskriftif yaitu dari hasil tanggapan siswa. Dan penelitian ini menggunakan pendekatan Penelitian dan Pengembangan (Research and Development) dengan model Analysis, Design, Development, Implementation, Evaluation (ADDIE). Simatupang, H., \& Siregar, E. H. (2017).

\section{Populasi dan Sampel Penelitian}

Penelitian dilakukan di SMA Negeri 14 Medan yang terletak di Jl. Pelajar Gg. Darmo, Binjai, Medan Denai, Kota Medan, Sumatera Utara. Sampel penelitian ini adalah kelas X MIA-3 yang berjumlah 34 siswa. Populasi penelitian ini yaitu seluruh kelas X MIA, dimana pengambilan sampel, diambil secara simple random sampling dilakukan dengan cara pengundian dan hasil undian yang didapat yaitu kelas X MIA-3.

\section{Subjek Penelitian}

Subjek penelitian adalah satu dosen biologi ahli materi, satu dosen biologi ahli pembelajaran, satu dosen biologi ahli desain, satu guru biologi SMA Negeri 14 Medan, dan siswa kelas X MIA-3 SMA Negeri 14 Medan sebanyak 34 orang. Dimana pada penelitian ini digunakan satu kelas sebagai kelas eksperimen yang diajarkan dengan menggunakan LKPD STEM. Objek Penelitian dalam penelitian ini adalah kelayakan bahan ajar berupa LKPD dengan pendekatan STEM dengan tujuan untuk menumbuhkan keterampilan literasi sains siswa pada materi virus siswa SMA kelas X MIA. Kelayakan bahan ajar tersebut dilihat dari segi kevalidan, dan keefektifan.

\section{HASIL DAN PEMBAHASAN}

Penelitian ini dilaksanakan 3 kali pertemuan, pertemuan pertama senin, tanggal 07 oktober 2019, selasa, tanggal 08 oktober 2019 dan senin, tanggal 14 maret 2019. Dimana pada pertemuan pertama dilakukan dengan cara pemberian soal-soal pada LKPD berbasis STEM yang terdapat didalam kegiatan Sains, pada pertemuan kedua pembuatan poster pada LKPD berbasis STEM yang terdapat didalam kegiatan Teknologi dan Teknik sedangkan pada pertemuan yang ketiga membahas tentang kegiatan Matematika yang terdapat pada LKPD berbasis STEM. Terlebih dahulu sebelum produk LKPD berbasis STEM pada materi virus sendiri diujikan ke siswa, LKPD divalidasi oleh validator yaitu validator ahli materi oleh Bapak Ahmad Shafwan Pulungan, S.Pd.,M.Si., validator ahli pembelajaran oleh Ibu Nanda Pratiwi, M.Pd., validator ahli desain oleh Bapak Eko Prasetya, S.Pd., M.Sc. Sehingga setelah LKPD yang dikembangkan sudah valid/layak digunakan kemudian dilakukanlah proses pengujian kesekolah untuk mendapatkan hasil penilaian dari guru bidang study biologi dan mengetahui keefektifan LKPD dalam menumbuhkan keterampilan literasi sains siswa.

\section{Hasil Validasi LKPD oleh Ahli Materi}

Persentase penilaian dari ahli materi berada dalam kategori "Sangat Layak" dengan persentase penilaian indikator kelayakan penyajian materi sebesar 87,5 \%, indikator komponen STEM sebesar 100\%, dan indikator kebahasaan sebesar 75\%. Persentase rata- 
rata kelayakan materi LKPD dengan pendekatan STEM pada materi virus dari ahli materi 87,5\% dengan kategori "Sangat Layak", sehingga bahan ajar yang telah dikembangkan dinyatakan layak digunakan.

\section{Hasil Validasi LKPD oleh Ahli Pembelajaran}

Persentase penilaian dari ahli pembelajaran berada dalam kategori "Sangat Layak" dengan persentase penilaian indikator kelayakan isi sebesar 90\%, indikator komponen STEM sebesar 87,5\%, dan indikator penggunaan bahasa sebesar 100\%. Secara keseluruhan Persentase rata-rata kelayakan pembelajaran LKPD dengan pendekatan STEM pada materi virus dari ahli pembelajaran 92,5\% dengan kategori "Sangat Layak", sehingga bahan ajar yang telah dikembangkan dinyatakan layak digunakan, syarat kelayakan sesuai BSNP untuk digunakan sebagai pendukung dalam proses pembelajaran fisika di SMA. Hasil ini sesuai dengan penelitian yang dilakukan oleh Arafah, dkk (2012) yang menyatakan bahwa LKPD hasil pengembangan yang merujuk pada BSNP dinyatakan sangat layak dan efektif digunakan dalam proses pembelajaran.

\section{Hasil Validasi LKPD oleh Ahli Desain}

Persentase penilaian dari ahli desain berada dalam kategori "Layak" dengan persentase penilaian indikator penyajian komponen sebesar 81,2\%, indikator komponen STEM sebesar 75\%, dan indikator kegrafikan sebesar $80 \%$. Persentase rata-rata kelayakan desain LKPD dengan pendekatan STEM pada materi virus dari ahli desain 78,7\% dengan kategori "Layak", sehingga bahan ajar yang telah dikembangkan dinyatakan layak digunakan.

\section{Hasil Penilaian LKPD oleh Guru Biologi}

Presentase penilaian guru biologi disimpulkan bahwa LKPD dengan pendekatan STEM pada materi virus kelas X MIA berada pada kriteria "Sangat Layak" dengan rata-rata persentase 97,3\%. LKPD yang dikembangkan dinyatakan layak dan dapat membantu pembelajaran biologi, Rissanen, A. (2014), LKPD berbasis STEM yang Telah valid memberikan kemudahan siswa dalam memahami suatu materi pembelajaran.

\section{Hasil Penilaian Tanggapan/Respon Peserta Didik}

Hasil kesimpulan tanggapan siswa terhadap LKPD berbasis STEM pada materi virus yang diberikan kepada 34 siswa. Hal ini dilakukan untuk mengetahui tanggapan siswa terhadap produk LKPD yang telah dirancang. Bahwa kesimpulan yang didapatkan dari hasil tanggapan siswa terhadap LKPD yang dikembangkan adalah nilai rata-rata presentase dari ke 34 siswa 95,8 \% yang memilih "iya", sehingga dapat disimpulkan bahwa LKPD yang diberikan baik digunakan atau layak digunakan dalam pembelajaran.

\section{Data Hasil Belajar Siswa Pada Uji Coba Kelompok Terbatas Terhadap Keefektifan LKPD Dalam Menumbuhkan Keterampian Literasi Sains}

Keefektifan LKPD dalam menumbuhkan keterampilan literasi sains dilihat dari ketercapaian pelaksanan pembelajaran secara ketuntasan individu dan ketuntasan secara klasikal serta pengamatan aktitivas siswa dalam pembelajaran. Dari data hasil analisis penggunaan LKPD berbasis STEM dirancang pada kelompok kelas terbatas didapatkan skor rata-rata 81,7 dengan jumlah persentase ketuntasan sebesar 85,2\%. LKPD yang di susun memuat pertanyaan dan masalah yang berkaitan dengan kehidupan sehari-hari, Prastowo, A (2015). Lembar kegiatan yang disusun dengan mencantumkan pertanyaan-pertanyaan dan masalah-masalah dapat membuat peserta didik aktif dalam mengikuti proses pembelajaran . 


\section{Hasil Uji Coba Kelompok Terbatas Dalam Menumbuhkan Keterampilan Literasi Sains}

Uji coba kelompok terbatas dilakukan di SMA Negeri 14 Medan. Uji coba ini dilakukan terhadap 34 orang siswa kelas X MIA-3 dengan kemampuan rendah, sedang, dan tinggi. Berdasarkan tabel 11, terlihat bahwa jumlah siswa yang tuntas hasil belajarnya 29 siswa dengan presentase $85,2 \%$ dan yang tidak tuntas hasil belajarnya 5 siswa dengan presentase $14,7 \%$, dimana pada siswa yang mendapatkan hasil yang tidak tuntas dikarenakan pada kegiatan Matematika pada LKPD proses pengerjaanya mendapatkan nilai yang rendah sehingga setelah dijumlah keseluruhan nilainya dari mulai kegiatan awal hingga akhir mendapatkan nilai dibawah KKM. Keterampilan literasi sains siswa berada pada kategori sedang, tinggi dan sangat tinggi. Sehingga skor rata-rata keterampilan literasi sains siswa sebesar 81,7 dengan jumlah persentase ketuntasan sebesar 85,2\%, yang berada pada kategori "Sangat Tinggi". Dapat disimpulkan bahwa sesuai teori yang mengatakan bahwa Pembelajaran dikatakan berhasil secara klasikal jika minimal 85,0\% peserta didik mencapai tuntas, sedangkan data yang didapat jumlah persentase ketuntasan sebesar $85,2 \%$, sehingga LKPD yang diujikan kepada kelompok terbatas signifikan efektif dapat menumbuhkan keterampilan literasi sains siswa, temuan ini sejalan dengan penelitian Parwati. dkk (2015) dalam konteks lingkungan yang menunjukan pembelajaran STEM dapat membangun kreativitas, literasi sains dan kemampuan memecahkan masalah yang sangat diperlukan dalam menghadapi abadke 21. Interprestasi nilai akhir tes keterampilan literasi sains terhadap penggunaan LKPD ini dapat dilihat pada gambar berikut :

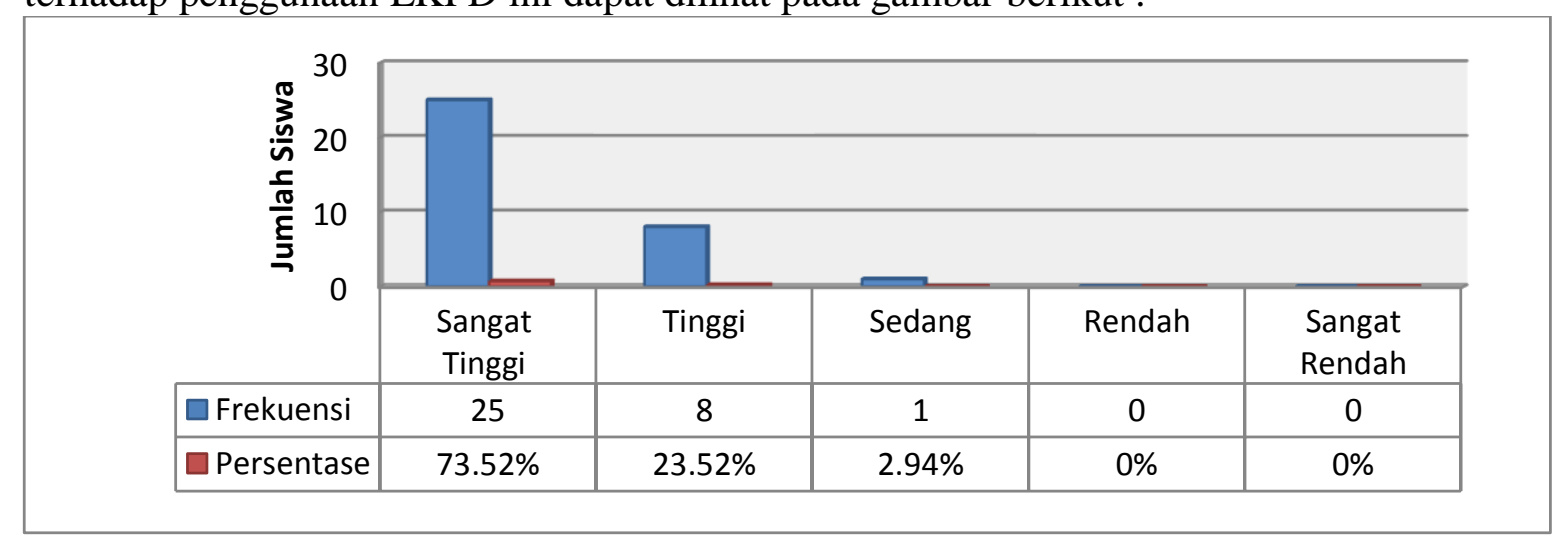

Gambar . Diagram Batang Hasil Tes Keterampilan Literasi Sains Siswa

\section{KESIMPULAN}

Berdasarkan rumusan, tujuan, hasil dan pembahasan perancangan LKPD berbasis Pendekatan STEM pada materi virus di kelas X yang dikemukakan sebelumnya dapat disimpulkan : 1) Penilaian ahli materi terhadap kelayakan LKPD berbasis STEM pada materi virus dikategorikan sangat layak $(87,5 \%)$, 2) Penilaian ahli pembelajaran terhadap kelayakan LKPD berbasis STEM pada materi virus dikategorikan sangat layak (92,5\%), 3) Penilaian ahli desain terhadap kelayakan LKPD berbasis STEM pada materi virus dikategorikan layak $(78,7 \%)$, 4) Penilaian guru biologi terhadap kelayakan LKPD berbasis STEM pada materi virus dikategorikan sangat layak (97,3\%), 5) Hasil tanggapan siswa terhadap kelayakan LKPD berbasis STEM pada materi virus dikategorikan baik $(95,8 \%)$, 6) LKPD berbasis Pendekatan STEM yang dirancang efektif menumbuhkan keterampilan literasi sains $(81,7)$ yang berada pada kategori sangat tinggi $(85,2 \%)$ sehingga baik digunakan dalam proses pembelajaran biologi pada materi virus

\section{DAFTAR PUSTAKA}


Silvia A, Simatupang H : Pengembangan LKPD Berbasis Science, Technology, Engineering, and Mathematics Untuk Menumbuhkan Keterampilan Literasi Sains Siswa Kelas X MIA SMA Negeri 14 Medan TP 2019/2020

Arafah, S. F., S. Ridhlo, \& B. Priyono. 2012. Pengembangan LKS Berbasis Berpikir Kritis pada Materi Animalia. Unnes Journal of Biology Education, 1(1): 47-53.

Jauhariyyah, R,F. (2017). Science, Technology, Engineering and Mathematics Project Based Learning (STEM-PjBL) Pada Pembelajaran Sains. Pros. Seminar Pend. IPA Pascasarjana UM. Vol.2.

Khairiyah, Nida'ul. 2019. Pendekatan Science, Teknology, Enginering dan Matematics (STEM). Medan: Guepedia.

Parwati, R., Anna Permanasari, Harry Firman, Tatang Suheri (2015). Studi pendahuluan: Potret mata kuliah Kimia Lingkungan di beberapa LPTK. Jurnal JPII, UNNES, Semarang. Vol 4(1), 1-7.

Pertiwi, R. S. (2017). Pengembangan Lembar Kerja Siswa Dengan Pendekatan Stem (Science, Technology, Engineering, Mathematics) Untuk Melatih Keterampilan Berpikir Kreatif Siswa Pada Materi Fluida Statis (diakses tanggal 30 Januari 2019).

Prastowo, A. 2015. Panduan Kreatif Membuat Bahan Ajar Inovatif. Jogjakarta: DIVA press.

Rissanen, A. 2014. Active and Peer

Learning in STEM Education

Strategy. Science Education

International, Vol. 25(1), 1-7.

Simatupang, H., \& Siregar, E. H. (2017). Pengembangan Bahan Ajar Praktikum Biologi Umum I Berbasis Inkuiri Untuk Meningkatkan Keterampilan Ilmiah Mahasiswa Biologi Angkatan 2015. Jurnal Handayani Pgsd Fip Unimed, 6(2), 17-23.

Toharudin,U., Hendrawati, S., \& Rustaman, A., 2011. Membangun Literasi Sains Peserta Didik. Bandung: Humaniora. 